\title{
IMPLEMENTASI MANAJEMEN RISIKO KLINIS DAN FAKTOR-FAKTOR YANG MEMPENGRUHI PADA RUMAH SAKIT DI KOTA MAKASSAR
}

\section{CLINICAL RISK MANAGEMENT IMPLEMENTATION AND IT'S INFLUENCING FACTORS IN HOSPITAL IN MAKASSAR}

\author{
Marsella Wahyuni Olii ${ }^{1}$, Fridawaty Rivai ${ }^{2}$, Sukri Palutturi ${ }^{3}$ \\ ${ }^{1}$ Bagian SDM, RS Dr. Tadjuddin Chalid Makassar \\ ${ }^{2}$ Bagian Administrasi Rumah Sakit, Fakultas Kesehatan Masyarakat, Universitas Hasanuddin \\ ${ }^{3}$ Bagian Administrasi dan Kebijakan Kesehatan, Fakultas Kesehatan Masyarakat, Universitas \\ Hasanuddin \\ Alamat Koresponden: Bagian SDM RS Dr. Tadjuddin Chalid Makassar, \\ marsellarstc@gmail.com
}

\begin{abstract}
ABSTRAK
Keselamatan pasien masih menjadi fokus perhatian utama dalam pelayanan kesehatan karena risiko yang terkait dengan pemberian pelayanan tersebut tidak akan dapat dihilangkan secara total dan insiden terkait pelayanan kesehatan masih sangat tinggi. Penelitian ini ingin melihat sejauh mana tingkat implementasi MRK pada rumah sakit di Kota Makassar dan faktor-faktor apa yang mempengaruhi implementasi tersebut. Metode yang digunakan dalam penelitian ini adalah metode penelitian kombinasi dengan desain sequential explanatory (urutan pembuktian). Data diperoleh melalui kuesioner dan wawancara mendalam. Pada tahap pertama dilakukan analisa dengan menggunakan metode kuantitatif deskriptif untuk menentukan tingkat kemapanan implementasi MRK di rumah sakit dan pada tahap kedua digunakan metode kualitatif untuk mengeksplorasi faktor-faktor yang mempengaruhi tingkat implementasi tersebut. Dari 9 rumah sakit sakit yang dilakukan penelitian, 7 diantaranya memiliki tingkat kemapanan implementasi MRK yang tinggi (77,78\%). Beberapa karakteristik struktural organisasi menunjukkan kecenderungan positif terhadap implementasi MRK, yaitu kelas dan status kepemilikan rumah sakit, sedangkan jenis rumah sakit tidak menunjukkan kecenderungan adanya hubungan. Terdapat 5 faktor yang berhasil diidentifikasi dan memiliki kecenderungan positif terhadap implementasi MRK yaitu kepemimpinan, pengetahuan staf, kordinator dan kebijakan rumah sakit, dan akreditasi.
\end{abstract}

Kata Kunci: Risiko, Manajemen Risiko Klinis, Keselamatan Pasien, Kepemimpinan, Akreditasi

\section{ABSTRACT}

Patient safety become a major concern in health care because the risks associated with health services can never be totally eliminated and the incidence related with patient care are huge in number. This study aims to assess the CRM maturity of hospital in Makassar and to identify the key factors related to CRM implementation. Mixed method was performed in this study by using sequential explanatory design. Questionnaire and deep interview were conducted to collect data. At the first step, analysis with the quantitative descriptive method was performed to assess the maturity level of hospital's CRM and then for the second step qualitative method was conducted to explore all possible factors related with CRM implementation. 7 out of 9 hospitals in this study reached high CRM maturity (77,78\%). Some organizational structure characteristic shows positive relation with CRM maturity, they are Hospital size 
JKMM, Vol. 2 No. 1, Desember 2019

(class) and legal body (ownership) but not with hospital type. Five factors were identified to have a positive relation with CRM maturity; they are leadership, staff knowledge, designated persons responsible for CRM coordination, strategic CRM objectives/policy and accreditation.

Key words: Risk, Clinical Risk Management, Patient safety, leadership, accreditation 


\section{PENDAHULUAN}

Keamanan dan keselamatan pasien masih menjadi fokus perhatian utama dalam pelayanan kesehatan karena risiko yang terkait dengan pemberian pelayanan tersebut tidak dapat dihilangkan sepenuhnya dan dampak yang ditimbulkan sangat besar. Layanan kesehatan yang tidak aman dan memiliki potensi risiko yang mengancam nyawa menjadi penyebab utama kematian dan peningkatan angka mortalitas pada pasien yang dirawat di rumah sakit di berbagai Negara. Beberapa penelitian mengungkapkan bahwa sekitar 2.9\%-16.6\% pasien mengalami kejadian yang tidak diinginkan dan 5\%-13\% diantaranya berakibat pada kematian, dimana $50 \%$ dari kejadian ini sebenarnya dapat dicegah (Adibi et al., 2012). Selain dampak yang ditimbulkan kepada pasien, masalah ini juga memiliki pengaruh yang signifikan terhadap faktor sosioekonomi dan menyebabkan beban finansial yang sangat signifikan terhadap sistem pelayanan kesehatan (Farokhzadian et al., 2015). Oleh karena itu maka program identifikasi risiko menjadi sangat penting untuk efisiensi dan efektifitas pelayanan, dan untuk mengatasi tantangan ini maka perlu penerapan dan pengembangan Manajemen Risiko Klinis yang sistematis (Briner et al., 2013), (Adibi et al., 2012). The Institute of Medicine (IOM) dalam laporannya mengindikasikan bahwa sebagian besar risiko klinis bersumber dari permasalahan dan insufisiensi pada sistem pelayanan kesehatan (Adibi et al., 2012). Dan meskipun WHO telah menekankan Implementasi Manajemen Risiko Klinis, namun masih banyak indikator yang menunjukkan bahwa pelayanan kesehatan masih belum aman seperti yang diharapkan dan bahwa hak-hak pasien masih belum sepenuhnya dipenuhi.

Manajemen risiko memainkan peran yang sangat penting dalam mencegah dan menangani kesalahan medis. Beberapa penelitian menunjukkan bahwa menciptakan pemahaman yang luas dan mendalam tentang manajemen kesalahan medis dapat meningkatkan pelayanan kepada pasien yang berhubungan dengan pelaporan insiden (Zaboli et al., 2011), dan bahwa penerapan manajemen risiko telah terbukti mampu menurunkan angka kesalahan pada unit gawat darurat (Zimmer et al., 2010). Pendekatan yang berdasar pada manajemen risiko prospektif dapat secara efektif meningkatkan keselamatan di rumah sakit (Pretagostini et al., 2010). Neale Graham dalam penelitiannya menunjukkan bahwa $20 \%$ insiden terjadi di dalam kamar operasi dan bahwa penerapan manajemen risiko dapat mengurangi angka kejadian tersebut. Demikian juga dengan Handel yang menyatakan bahwa penerapan program manajemen risiko dapat secara efektif mengurangi angka kesalahan medis (Zaboli et al., 2011).

Penting bagi rumah sakit untuk menilai status kemapanan implementasi manajemen risiko yang mereka miliki sebagai dasar dan penunjuk arah dalam pengembangan program manajemen risiko klinis. Penilaian terhadap manajemen risiko di rumah sakit adalah infrastruktur dari suatu perencanaan penerapan manajemen krisis yang merupakan salah satu isu mendasar di dunia kedokteran (Zaboli et al., 2011). Hasil penelitian Zaboli et al., 2011 di rumah sakit di Kota Tehran pada Tahun 2011 menunjukkan minimnya kebijakan dan prosedur terkait manajemen risiko di bangsal. Dalam penelitian yang terkait dengan 
Manajemen Risiko Klinis di beberapa negara, telah berhasil diidentifikasi hambatanhambatan dalam penerapannya, antara lain beban kerja yang tinggi, kurangnya sumber daya keuangan dan fisik, budaya organisasi, program pelatihan yang tidak memadai, pendidikan yang tidak memadai (Adibi et al., 2012), pergantian manager yang cepat, kurangnya dukungan kepemimpinan, dan kurangnya penilaian dan pengawasan terhadap jalannya program Manajemen Risiko Klinis (Dehnavieh et al., 2013). Meskipun telah banyak literatur dan penelitian yang mengungkapkan berbagai komponen dan instrumen dari Manajemen Risiko Klinis (checklist, sistem pelaporan insiden, metode-metode penilaian risiko), namun masih sedikit yang mengkaji implementasi dan tingkat kemapanan penerapan Manajemen Risiko Klinis secara keseluruhan (tingkat pengembangan Manajemen Risiko Klinis) di rumah sakit (Briner et al., 2013), apalagi di Indonesia, terkhusus Kota Makassar. Oleh karena itu maka penelitian ini bertujuan untuk menilai tingkat kemapanan penerapan Manajemen Risiko Klinis pada rumah sakit di Kota Makassar serta faktor-faktor yang mempengaruhinya.

\section{BAHAN DAN METODE}

\section{Lokasi dan Rancangan penelitian}

Penelitian ini dilakukan di 9 rumah sakit di Kota Makassar yang mewakili masing-masing karakteristik struktur organisasi. Jenis penelitian yang digunakan adalah penelitian kombinasi dengan desain sequential explanatory (urutan pembuktian).

\section{Populasi dan sampel}

Populasi penelitian ini adalah seluruh rumah sakit yang ada di Kota Makassar, berjumlah 48 rumah sakit. Pemilihan sampel dilakukan secara non probability sampling dengan menggunakan teknik purposive sampling. Sampel yang diambil mewakili keseluruhan faktor struktural organisasi rumah sakit yang meliputi kelas rumah sakit (A, B dan C), status kepemilikan rumah sakit (pemerintah, swasta, TNI/Polri), jenis rumah sakit (umum, khusus dan pendidikan), dengan total 9 (Sembilan) rumah sakit. Responden adalah Ketua Komite Mutu atau penanggungjawab program mutu/manajemen risiko di rumah sakit.

\section{Metode pengumpulan data}

Pengumpulan data dilakukan melalui pengisian kuesioner oleh responden yang diadaptasi dari Briner, yang merupakan suatu instrument monitoring penerapan Manajemen Risiko Klinis di rumah sakit yang mampu memberikan gambaran implementasi Manajemen Risiko Klinis di rumah sakit baik pada tingkat organisasi maupun tingkat unit pelayanan. Instrumen tersebut berupa kuesioner yang terdiri 28 pertanyaan utama dengan total 101 pertanyaan. Poin-poin pertanyaan yang sesuai dikelompokkan dan diberi indeks (Gambar 1). Setelah itu dilakukan wawancara mendalam (indepth interview) untuk mengeksplorasi dan menggali informasi lebih dalam dari responden. 
Olii, 2019

Gambar 1. Indeks Manajemen Risiko Klinis pada Tingkat Organisasi Rumah Sakit dan Tingkat Unit Layanan

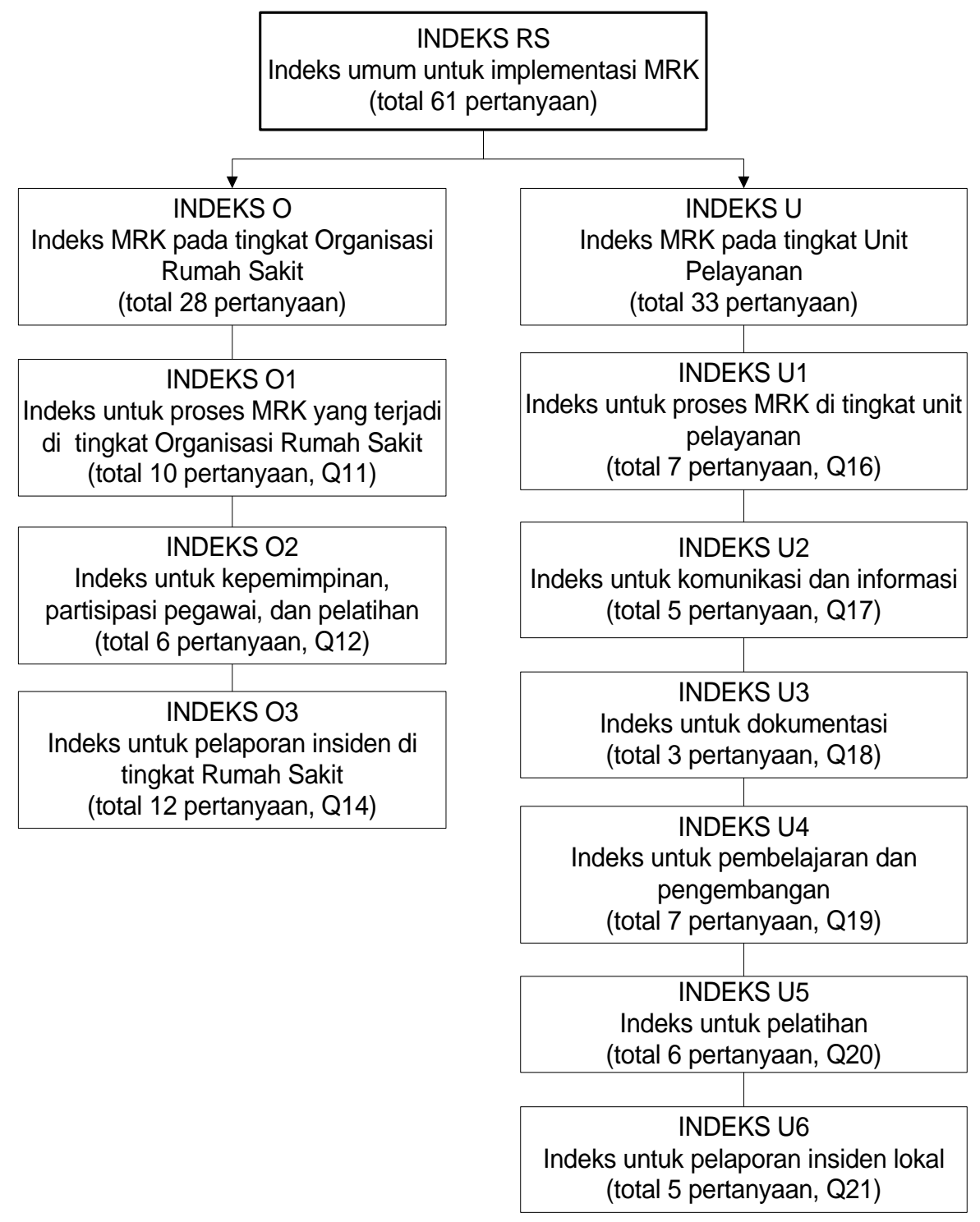

\section{Analisis data}

Pada tahapan metode kuantitatif digunakan teknik analisis data secara statistik deskriptif untuk menilai dan mengkategorikan tingkat kemapanan implementasi Manajemen Risiko Klinis di setiap rumah sakit berdasarkan tahapan perubahan organisasi sesuai model transteoritikal. Kemudian dalam tahapan metode kualitatif, dilakukan eksplorasi dan content analysis terhadap hasil wawancara.

\section{HASIL}

\section{Karakteristik sampel}

Tabel 1 memperlihatkan krakteristik rumah sakit yang menjadi sampel dalam penelitian ini. 9 rumah sakit yang dipilih mewakili karakteristik struktur organisasi rumah sakit yang meliputi jenis, kelas dan 
kepemilikan rumah sakit, serta status akreditasi. Berdasarkan jenis rumah sakit terdapat 7 rumah sakit umum dan 2 rumah sakit khusus. Berdasarkan kelas rumah sakit terdapat 2 rumah sakit kelas A, 6 rumah sakit kelas B dan 1 rumah sakit kelas C. Berdasarkan kepemilikan rumah sakit terdapat 4 rumah sakit pemerintah pusat, 3 rumah sakit pemerintah daerah dan 2 rumah sakit swasta, sedangkan berdasarkan status akreditasi terdapat 6 rumah sakit yang telah terakreditasi dan 3 sisanya belum terakreditasi.

Tabel 1. Karakteristik Rumah Sakit Responden

\begin{tabular}{|c|c|c|c|c|c|c|c|c|c|c|}
\hline \multirow[t]{2}{*}{ Responden } & \multicolumn{2}{|c|}{ Jenis RS } & \multicolumn{3}{|c|}{ Kelas RS } & \multicolumn{3}{|c|}{ Kepemilikan RS } & \multicolumn{2}{|c|}{ Akreditasi } \\
\hline & Umum & Khusus & $\mathrm{A}$ & B & $\mathrm{C}$ & Pusat & Daerah & Swasta & $\mathrm{Ya}$ & Tdk \\
\hline WS & $\sqrt{ }$ & & $\sqrt{ }$ & & & $\sqrt{ }$ & & & $\sqrt{ }$ & \\
\hline $\mathbf{L B}$ & $\sqrt{ }$ & & & $\sqrt{ }$ & & & $\sqrt{ }$ & & & $\sqrt{ }$ \\
\hline SR & $\sqrt{ }$ & & & & $\sqrt{ }$ & & $\sqrt{ }$ & & & $\sqrt{ }$ \\
\hline TC & & $\sqrt{ }$ & $\sqrt{ }$ & & & $\sqrt{ }$ & & & $\sqrt{ }$ & \\
\hline $\mathbf{A B}$ & $\sqrt{ }$ & & & $\sqrt{ }$ & & & & $\sqrt{ }$ & $\sqrt{ }$ & \\
\hline UH & $\sqrt{ }$ & & & $\sqrt{ }$ & & $\sqrt{ }$ & & & & $\sqrt{ }$ \\
\hline $\mathbf{P L}$ & $\sqrt{ }$ & & & $\sqrt{ }$ & & $\sqrt{ }$ & & & $\sqrt{ }$ & \\
\hline SM & $\sqrt{ }$ & & & $\sqrt{ }$ & & & & $\sqrt{ }$ & $\sqrt{ }$ & \\
\hline PW & & $\sqrt{ }$ & & $\sqrt{ }$ & & & $\sqrt{ }$ & & $\sqrt{ }$ & \\
\hline
\end{tabular}

\section{Tingkat Kemapanan Implementasi Manajemen Risiko Klinis Rumah Sakit Responden}

Pada table 2 terlihat bahwa 7 dari 9 $(77,78 \%)$ rumah sakit responden memiliki tingkat kemapanan implementasi Manajemen Risiko Klinis yang tinggi, sedangkan 2 rumah sakit lainnya $(22,22 \%)$ memiliki tingkat kemapanan implementasi Manajemen Risiko Klinis yang rendah. Jumlah sampel yang berada pada level implementasi Manajemen Risiko Klinis yang tinggi dan rendah sama pada semua indeks penilaian, baik pada tingkat organisasi (indeks O) maupun tingkat unit pelayanan (indeks $\mathrm{U}$ ), meskipun pada tingkat unit pelayanan nilai indeksnya lebih bervariasi. Pada rumah sakit yang memiliki tingkat kemapanan implementasi Manajemen Risiko Klinis yang tinggi, nilai indeks $\mathrm{O}$ dan indeks $\mathrm{U}$ tidak menunjukkan perbedaan yang besar, hanya sebesar 0,01\%. Hal sebaliknya ditemukan pada rumah sakit yang memiliki tingkat kemapanan implementasi Manajemen Risiko Klinis yang rendah, yaitu mereka menunjukkan perbedaan yang cukup besar antara indeks $\mathrm{O}$ dan indeks $\mathrm{U}$ yaitu sebesar $17,77 \%$ dengan nilai indeks $U$ yang lebih besar. Untuk rumah sakit dengan tingkat implementasi Manajemen Risiko Klinis yang tinggi, pada tingkat organisasi (indeks O), indeks yang memiliki nilai rata-rata tertinggi adalah indeks $\mathrm{O} 2$ yang merupakan indeks untuk kepemimpinan, partisipasi pegawai dan pelatihan dengan nilai 97,62\%. Hal sebaliknya ditemukan pada rumah sakit dengan tingkat implementasi Manajemen Risiko Klinis rendah, dimana indeks O2 mendapatkan nilai 0 . 
Olii, 2019

Tabel 2. Tingkat Kemapanan Manajemen Risiko Klinis pada Rumah Sakit Responden

\begin{tabular}{|c|c|c|}
\hline INDEKS MRK & $\%$ & $\begin{array}{c}\text { TINGKAT } \\
\text { KEMAPANAN }\end{array}$ \\
\hline \multicolumn{3}{|l|}{ 1. WS } \\
\hline $\begin{array}{l}\text { Indeks RS, Indeks umum untuk rumah sakit, terdiri dari Indeks O dan } \\
\text { Indeks U }\end{array}$ & 87.5 & Tinggi \\
\hline \multicolumn{3}{|l|}{ Tingkat RS } \\
\hline $\begin{array}{l}\text { Indeks Oganisasi }(\mathrm{O}) \text {, indeks MRK pada tingkat organisasi rumah } \\
\text { sakit, terdiri dari indeks } \mathrm{O} 1, \mathrm{O} 2 \text {, dan } \mathrm{O} 3\end{array}$ & 78.57 & Tinggi \\
\hline - Indeks O1, indeks untuk proses MRK yang sedang berjalan & 100 & Tinggi \\
\hline $\begin{array}{l}\text { - Indeks } \mathrm{O} 2 \text {, indeks untuk kepemimpinan, partisipasi pegawai } \\
\text { dan pelatihan }\end{array}$ & 100 & Tinggi \\
\hline - Indeks O3, indeks untuk pelaporan insiden di rumah sakit & 50 & Tinggi \\
\hline \multicolumn{3}{|l|}{ Tingkat Unit Pelayanan } \\
\hline $\begin{array}{l}\text { Indeks Unit (U), indeks MRK pada tingkat unit pelayanan, terdiri } \\
\text { dari indeks U1 sampai U6 }\end{array}$ & 96.43 & Tinggi \\
\hline $\begin{array}{l}\text { - Indeks U1, indeks untuk proses MRK yang sedang berjalan } \\
\text { di unit pelayanan }\end{array}$ & 100 & Tinggi \\
\hline - Indeks U2, indeks untuk komunikasi dan informasi & 100 & Tinggi \\
\hline - Indeks U3, indeks untuk dokumentasi & 100 & Tinggi \\
\hline - Indeks U4, indeks untuk pembelajaran dan pengembangan & 100 & Tinggi \\
\hline - Indeks U5, indeks untuk pelatihan & 83.33 & Tinggi \\
\hline - Indeks U6, indeks untuk pelaporan insiden lokal & - & - \\
\hline \multicolumn{3}{|l|}{${ }^{2}$} \\
\hline $\begin{array}{l}\text { Indeks RS, Indeks umum untuk rumah sakit, terdiri dari Indeks O dan } \\
\text { Indeks U } \\
\text { Tingkat RS }\end{array}$ & 30.36 & Rendah \\
\hline $\begin{array}{l}\text { Indeks Oganisasi }(\mathrm{O}) \text {, indeks MRK pada tingkat organisasi rumah } \\
\text { sakit, terdiri dari indeks } \mathrm{O} 1, \mathrm{O} 2 \text {, dan } \mathrm{O} 3\end{array}$ & 17.86 & Rendah \\
\hline - Indeks O1, indeks untuk proses MRK yang sedang berjalan & 0 & Rendah \\
\hline $\begin{array}{l}\text { - Indeks } \mathrm{O} 2 \text {, indeks untuk kepemimpinan, partisipasi pegawai } \\
\text { dan pelatihan }\end{array}$ & $\begin{array}{c}0 \\
41.67\end{array}$ & Rendah \\
\hline - Indeks O3, indeks untuk pelaporan insiden di rumah sakit & & Rendah \\
\hline \multicolumn{3}{|l|}{ Tingkat Unit Pelayanan } \\
\hline $\begin{array}{l}\text { Indeks Unit (U), indeks MRK pada tingkat unit pelayanan, terdiri } \\
\text { dari indeks U1 sampai U6 }\end{array}$ & 42.86 & Rendah \\
\hline $\begin{array}{l}\text { - Indeks U1, indeks untuk proses MRK yang sedang berjalan } \\
\text { di unit pelayanan }\end{array}$ & 14.29 & Rendah \\
\hline - Indeks U2, indeks untuk komunikasi dan informasi & 60 & Tinggi \\
\hline - Indeks U3, indeks untuk dokumentasi & 33.33 & Rendah \\
\hline - Indeks U4, indeks untuk pembelajaran dan pengembangan & 57.14 & Tinggi \\
\hline - Indeks U5, indeks untuk pelatihan & 50 & Tinggi \\
\hline - Indeks U6, indeks untuk pelaporan insiden lokal & - & - \\
\hline \multicolumn{3}{|l|}{ 3. SR } \\
\hline \multirow{2}{*}{$\begin{array}{l}\text { Indeks RS, Indeks umum untuk rumah sakit, terdiri dari Indeks O da } \\
\text { Indeks U } \\
\text { Tingkat RS }\end{array}$} & 8.93 & Rendah \\
\hline & 3.57 & Rendah \\
\hline
\end{tabular}


Indeks Oganisasi $(\mathrm{O})$, indeks MRK pada tingkat organisasi rumah sakit, terdiri dari indeks $\mathrm{O} 1, \mathrm{O} 2$, dan $\mathrm{O} 3$

- Indeks O1, indeks untuk proses MRK yang sedang berjalan

Rendah

- Indeks O2, indeks untuk kepemimpinan, partisipasi pegawai dan pelatihan

$0 \quad$ Rendah

- Indeks O3, indeks untuk pelaporan insiden di rumah sakit

$8.33 \quad$ Rendah

Tingkat Unit Pelayanan

Indeks Unit (U), indeks MRK pada tingkat unit pelayanan, terdiri

14.29

Rendah dari indeks U1 sampai U6

- Indeks U1, indeks untuk proses MRK yang sedang berjalan di unit pelayanan

- Indeks U2, indeks untuk komunikasi dan informasi

- Indeks U3, indeks untuk dokumentasi

- Indeks U4, indeks untuk pembelajaran dan pengembangan

- Indeks U5, indeks untuk pelatihan

\section{0}

20

0

42.86

0

- Indeks U6, indeks untuk pelaporan insiden lokal

\section{TC}

Indeks RS, Indeks umum untuk rumah sakit, terdiri dari Indeks O dan Indeks U

Tingkat RS

Tingkat Unit Pelayanan

Indeks Oganisasi (O), indeks MRK pada tingkat organisasi rumah sakit, terdiri dari indeks $\mathrm{O} 1, \mathrm{O} 2$, dan $\mathrm{O} 3$

- Indeks O1, indeks untuk proses MRK yang sedang berjalan

- Indeks O2, indeks untuk kepemimpinan, partisipasi pegawai dan pelatihan

- Indeks O3, indeks untuk pelaporan insiden di rumah sakit

Indeks Unit (U), indeks MRK pada tingkat unit pelayanan, terdiri dari indeks U1 sampai U6

- Indeks U1, indeks untuk proses MRK yang sedang berjalan di unit pelayanan

- Indeks U2, indeks untuk komunikasi dan informasi

- Indeks U3, indeks untuk dokumentasi

71.43

70

100

58.33

60.71

42.86

- Indeks U4, indeks untuk pembelajaran dan pengembangan

- Indeks U5, indeks untuk pelatihan

- Indeks U6, indeks untuk pelaporan insiden lokal

\section{5. $\mathrm{AB}$}

Indeks RS, Indeks umum untuk rumah sakit, terdiri dari Indeks O dan Indeks U

Tingkat RS

Indeks Oganisasi $(\mathrm{O})$, indeks MRK pada tingkat organisasi rumah sakit, terdiri dari indeks $\mathrm{O} 1, \mathrm{O} 2$, dan $\mathrm{O} 3$

- Indeks O1, indeks untuk proses MRK yang sedang berjalan

- Indeks O2, indeks untuk kepemimpinan, partisipasi pegawai dan pelatihan

- Indeks O3, indeks untuk pelaporan insiden di rumah sakit

Tingkat Unit Pelayanan Indeks Unit (U), indeks MRK pada tingkat unit pelayanan, terdiri dari indeks U1 sampai U6 


\begin{tabular}{|c|c|c|}
\hline $\begin{array}{l}\text { - Indeks U1, indeks untuk proses MRK yang sedang berjalan } \\
\text { di unit pelayanan } \\
\text { - Indeks U2, indeks untuk komunikasi dan informasi } \\
\text { - Indeks U3, indeks untuk dokumentasi } \\
\text { - Indeks U4, indeks untuk pembelajaran dan pengembangan } \\
\text { - Indeks U5, indeks untuk pelatihan } \\
\text { - Indeks U6, indeks untuk pelaporan insiden lokal }\end{array}$ & $\begin{array}{c}100 \\
66.67 \\
100 \\
50 \\
-\end{array}$ & $\begin{array}{l}\text { Tinggi } \\
\text { Tinggi } \\
\text { Tinggi } \\
\text { Tinggi } \\
\quad-\end{array}$ \\
\hline 6. UH & & \\
\hline $\begin{array}{l}\text { Indeks RS, Indeks umum untuk rumah sakit, terdiri dari Indeks O dan } \\
\text { Indeks U } \\
\text { Tingkat RS }\end{array}$ & 85.71 & Tinggi \\
\hline $\begin{array}{l}\text { Indeks Oganisasi (O), indeks MRK pada tingkat organisasi rumah } \\
\text { sakit, terdiri dari indeks O1, O2, dan O3 } \\
\text { - Indeks O1, indeks untuk proses MRK yang sedang berjalan } \\
\text { - Indeks O2, indeks untuk kepemimpinan, partisipasi pegawai } \\
\text { dan pelatihan } \\
\text { - Indeks O3, indeks untuk pelaporan insiden di rumah sakit }\end{array}$ & $\begin{array}{l}100 \\
100\end{array}$ & $\begin{array}{l}\text { Tinggi } \\
\text { Tinggi }\end{array}$ \\
\hline $\begin{array}{l}\text { Tingkat Unit Pelayanan } \\
\text { Indeks Unit (U), indeks MRK pada tingkat unit pelayanan, terdiri } \\
\text { dari indeks U1 sampai U6 } \\
\text { - Indeks U1, indeks untuk proses MRK yang sedang berjalan } \\
\text { di unit pelayanan } \\
\text { - Indeks U2, indeks untuk komunikasi dan informasi } \\
\text { - Indeks U3, indeks untuk dokumentasi } \\
\text { - Indeks U4, indeks untuk pembelajaran dan pengembangan } \\
\text { - Indeks U5, indeks untuk pelatihan } \\
\text { - Indeks U6, indeks untuk pelaporan insiden lokal }\end{array}$ & $\begin{array}{l}80 \\
33.33 \\
85.71 \\
83.33 \\
-\end{array}$ & $\begin{array}{l}\text { Tinggi } \\
\text { Rendah } \\
\text { Tinggi } \\
\text { Tinggi } \\
\quad-\end{array}$ \\
\hline 7. PL & & \\
\hline $\begin{array}{l}\text { Indeks RS, Indeks umum untuk rumah sakit, terdiri dari Indeks O dan } \\
\text { Indeks U } \\
\text { Tingkat RS }\end{array}$ & 92.86 & Tinggi \\
\hline $\begin{array}{l}\text { Indeks Oganisasi }(\mathrm{O}) \text {, indeks MRK pada tingkat organisasi rumah } \\
\text { sakit, terdiri dari indeks } \mathrm{O} 1, \mathrm{O} 2 \text {, dan } \mathrm{O} 3\end{array}$ & 89.29 & Tinggi \\
\hline - Indeks O1, indeks untuk proses MRK yang sedang berjalan & 90 & Tinggi \\
\hline $\begin{array}{l}\text { - Indeks } \mathrm{O} 2 \text {, indeks untuk kepemimpinan, partisipasi pegawai } \\
\text { dan pelatihan }\end{array}$ & 83.33 & Tinggi \\
\hline $\begin{array}{l}\text { - Indeks O3, indeks untuk pelaporan insiden di rumah sakit } \\
\text { Tingkat Unit Pelayanan }\end{array}$ & 91.67 & Tinggi \\
\hline $\begin{array}{l}\text { Indeks Unit (U), indeks MRK pada tingkat unit pelayanan, terdiri } \\
\text { dari indeks U1 sampai U6 }\end{array}$ & 96.43 & Tinggi \\
\hline $\begin{array}{l}\text { - Indeks U1, indeks untuk proses MRK yang sedang berjalan } \\
\text { di unit pelayanan }\end{array}$ & 100 & Tinggi \\
\hline - Indeks U2, indeks untuk komunikasi dan informasi & 100 & Tinggi \\
\hline - Indeks U3, indeks untuk dokumentasi & 66.67 & Tinggi \\
\hline - Indeks U4, indeks untuk pembelajaran dan pengembangan & 100 & Tinggi \\
\hline - Indeks U5, indeks untuk pelatihan & 100 & Tinggi \\
\hline - Indeks U6, indeks untuk pelaporan insiden lokal & - & - \\
\hline \multicolumn{3}{|l|}{ 8. SM } \\
\hline $\begin{array}{l}\text { Indeks RS, Indeks umum untuk rumah sakit, terdiri dari Indeks O dan } \\
\text { Indeks U }\end{array}$ & 96.43 & Tinggi \\
\hline
\end{tabular}


Tingkat RS

Indeks Oganisasi (O), indeks MRK pada tingkat organisasi rumah sakit, terdiri dari indeks $\mathrm{O} 1, \mathrm{O} 2$, dan $\mathrm{O} 3$

- Indeks O1, indeks untuk proses MRK yang sedang berjalan

92.86 dan pelatihan

- Indeks O3, indeks untuk pelaporan insiden di rumah sakit

Tingkat Unit Pelayanan

Indeks Unit (U), indeks MRK pada tingkat unit pelayanan, terdiri dari indeks U1 sampai U6

- Indeks U1, indeks untuk proses MRK yang sedang berjalan di unit pelayanan

- Indeks U2, indeks untuk komunikasi dan informasi

- Indeks U3, indeks untuk dokumentasi

- Indeks U4, indeks untuk pembelajaran dan pengembangan

- Indeks U5, indeks untuk pelatihan

- Indeks U6, indeks untuk pelaporan insiden lokal

\section{PW}

Indeks RS, Indeks umum untuk rumah sakit, terdiri dari Indeks O dan Indeks U

Tingkat RS

Indeks Oganisasi (O), indeks MRK pada tingkat organisasi rumah sakit, terdiri dari indeks $\mathrm{O} 1, \mathrm{O} 2$, dan $\mathrm{O} 3$

- Indeks O1, indeks untuk proses MRK yang sedang berjalan

- Indeks O2, indeks untuk kepemimpinan, partisipasi pegawai dan pelatihan

- Indeks O3, indeks untuk pelaporan insiden di rumah sakit

Tingkat Unit Pelayanan

Indeks Unit (U), indeks MRK pada tingkat unit pelayanan, terdiri dari indeks U1 sampai U6

- Indeks U1, indeks untuk proses MRK yang sedang berjalan di unit pelayanan

- Indeks U2, indeks untuk komunikasi dan informasi

- Indeks U3, indeks untuk dokumentasi

- Indeks U4, indeks untuk pembelajaran dan pengembangan

- Indeks U5, indeks untuk pelatihan

- Indeks U6, indeks untuk pelaporan insiden lokal
90

100

Tinggi

Tinggi

Tinggi

$91.67 \quad$ Tinggi

$100 \quad$ Tinggi

$100 \quad$ Tinggi

$100 \quad$ Tinggi

$100 \quad$ Tinggi

100 Tinggi

$100 \quad$ Tinggi

-

$94.64 \quad$ Tinggi

Tinggi

$92.86 \quad$ Tinggi

$90 \quad$ Tinggi

$100 \quad$ Tinggi

$91.67 \quad$ Tinggi

$96.43 \quad$ Tinggi

100 Tinggi

$100 \quad$ Tinggi

100 Tinggi

100 Tinggi

83.33 Tinggi

Tingkat Kemapanan Implementasi

tinggi, 5 merupakan rumah sakit umum dan 2

Manajemen Risiko Klinis Berdasarkan Karakteristik Struktur Organisasi

Tabel 3 menunjukkan tingkat kemapanan implementasi Manajemen Risiko Klinis berdasarkan karakteristik masingmasing rumah sakit responden. Dari tabel tersebut terlihat bahwa Berdasarkan jenis rumah sakit, dari 7 rumah sakit dengan tingkat kemapanan Manajemen Risiko Klinis adalah rumah sakit khusus, sedangkan 2 rumah sakit dengan tingkat kemapanan Manajemen Risiko Klinis yang rendah semuanya merupakan rumah sakit umum. Berdasarkan kelas rumah sakit, dari 7 rumah sakit yang memiliki tingkat kemapanan Manajemen Risiko Klinis tinggi, 2 merupakan rumah sakit kelas A dan 5 rumah sakit kelas B, sedangkan 2 rumah sakit yang 
terkategorikan kemapanan Manajemen

Risiko Klinis rendah, 1 diantaranya rumah sakit kelas B dan 1 adalah rumah sakit kelas C. Berdasarkan kepemilikan, dari semua rumah sakit dengan tingkat kemapanan Manajemen Risiko Klinis tinggi, 4 merupakan rumah sakit pemerintah pusat, 1 rumah sakit milik pemerintah daerah, dan 2 merupakan rumah sakit swasta, sedangkan kedua rumah sakit yang memiliki tingkat kemapanan rendah merupakan rumah sakit milik pemerintah daerah. Sedangkan berdasarkan status akreditasi, dari 7 rumah sakit dengan tingkat kemapanan Manajemen Risiko Klinis tinggi, 6 rumah sakit telah terakreditasi dan 1 rumah sakit belum terakreditasi, sedangkan 2 rumah sakit yang memiliki tingkat kemapanan Manajemen Risiko Klinis rendah keduanya belum terakreditasi.

Tabel 3. Tingkat Kemapanan Manajemen Risiko Klinis Berdasarkan Karaketristik Organisasi Rumah Sakit Responden

\begin{tabular}{ccccccccccc}
\hline \multirow{2}{*}{ Tingkat } & \multicolumn{2}{c}{ Jenis RS } & \multicolumn{3}{c}{ Kelas RS } & \multicolumn{3}{c}{ Kepemilikan RS } & \multicolumn{2}{c}{ Akreditasi } \\
\cline { 2 - 10 } Kemapanan & Umum & Khusus & $\mathbf{A}$ & $\mathbf{B}$ & $\mathbf{C}$ & Pusat & Daerah & Swasta & Ya & Tdk \\
Tinggi & $\mathbf{n}(\boldsymbol{\%})$ & $\mathbf{n}(\boldsymbol{\%})$ & $\mathbf{n}(\boldsymbol{\%})$ & $\mathbf{n}(\boldsymbol{\%})$ & $\mathbf{n}(\boldsymbol{\%})$ & $\mathbf{n}(\boldsymbol{\%})$ & $\mathbf{n}(\boldsymbol{\%})$ & $\mathbf{n}(\boldsymbol{\%})$ & $\mathbf{n}(\boldsymbol{\%})$ & $\mathbf{n}(\boldsymbol{\%})$ \\
& 5 & 2 & 2 & 5 & - & 4 & 1 & 2 & 6 & 1 \\
Rendah & $(55,56)$ & $(22,22)$ & $(22,2)$ & $(22,2)$ & & $(44,44)$ & $(11,11)$ & $(22,22)$ & $(66,6)$ & $(11,11)$ \\
& $2(22,22)$ & - & - & 5 & 1 & - & 2 & - & - & 2 \\
& & & & $(11,1)$ & $(11,1)$ & & $(22,22)$ & & & $(22,22)$ \\
\hline
\end{tabular}

\section{PEMBAHASAN}

Dalam penelitian ini bahwa sebagian besar Rumah Sakit Umum memiliki tingkat implementasi Manajemen Risiko Klinis yang tinggi, dan demikian pula dengan Rumah Sakit Khusus yang semuanya terkategorikan memiliki implementasi Manajemen Risiko Klinis yang tinggi, sehingga tidak jelas terlihat pengaruh faktor jenis pelayanan rumah sakit terhadap tingkat kemapanan implementasi Manajemen Risiko Klinis.

Rumah sakit yang memiliki tingkat kemapanan MRK yang rendah adalah rumah sakit yang belum terakreditasi, sedangkan untuk rumah sakit yang memiliki tingkat kemapanan MRK tinggi, diantaranya adalah rumah sakit yang belum terakreditasi, namun rumah sakit ini sedang dalam proses mempersiapkan akreditasi dan telah melakukan upaya-upaya pemenuhan terhadap standar akreditasi KARS. Dalam penelitian ini jelas terlihat bahwa status akreditasi memberikan dampak positif terhadap peningkatan kualitas pelayanan rumah sakit secara umum dan termasuk juga terhadap implementasi MRK. Akreditasi memberikan panduan bagi rumah sakit tentang persyaratan dan elemen-elemen yang harus dipenuhi dalam pencapaian standar mutu yang dipersyaratkan, termasuk keharusan suatu rumah sakit untuk memiliki Komite Mutu atau tim lain yang bertanggungjawab terhadap peningkatan mutu (Kemenkes, 2011). Penelitian lain juga mengungkapkan bahwa pegawai yang bekerja di rumah sakit yang telah terakreditasi memiliki persepsi yang lebih positif tentang keselamatan pasien, dan menjadikan akreditasi sebagai salah satu prediktor major untuk budaya keselamatan pasien (El-Jardali et al., 2011). Meskipun dalam penelitian ini terdapat satu rumah sakit dengan tingkat implementasi MRK yang tinggi namun belum terakreditasi tapi rumah 
sakit tersebut sedang dalam proses persiapan akreditasi, yang berarti bahwa mereka telah melakukan berbagai upaya untuk memenuhi standar-standar yang dipersyaratkan dalam elemen penilaian.

Berdasarkan content analysis yang dilakukan terhadap hasil wawancara, beberapa faktor yang memiliki kecenderungan sebagai faktor kunci dalam implementasi Manajemen Risiko Klinis di rumah sakit adalah kepemimpinan, pengetahuan staf, dan terdapatnya posisi penanggungjawab program Manajemen Risiko Klinis dan kebijakan strategis rumah sakit. Hal ini sejalan dengan penelitian yang dilakukan oleh Zaboli, yang menyatakan bahwa variabel-variabel yang berpengaruh terhadap penerapan Manajemen Risiko Klinis di rumah sakit antara lain adalah pemahaman pegawai tentang manajemen risiko, kebijakan dan prosedur terkait manajemen risiko, pelatihan tentang manajemen risiko dan posisi program manajemen risiko di rumah sakit (Zaboli et all, 2011). Demikian pula hasil penelitian yang dilakukan di tiga rumah sakit pendidikan di Iran, menunjukkan bahwa pengetahuan yang rendah terkait konsep dan elemen-elemen Manajemen Risiko Klinis mengakibatkan rendahnya partisipasi pegawai dalam program Manajemen Risiko Klinis, seperti pelaporan dan analisis (Farokhzadian et al., 2015).

\section{KESIMPULAN DAN SARAN}

Penelitian ini menyimpulkan bahwa tingkat implementasi Manajemen Risiko Klinis pada rumah sakit di Kota Makassar cukup baik, dengan 77,78\% (7 dari 9) rumah sakit memiliki tingkat kemapanan implementasi Manajemen Risiko Klinis yang tinggi. Gambaran tingkat implementasi
Manajemen Risiko Klinis secara umum pada rumah sakit (indeks RS) ditemukan sama dengan implementasi Manajemen Risiko Klinis pada tingkat organisasi (indeks $\mathrm{O}$ ), sedangkan pada tingkat unit pelayanan (indeks U) hasilnya lebih bervariasi. Pada rumah sakit dengan tingkat kemapanan implementasi Manajemen Risiko Klinis yang tinggi, tidak terdapat perbedaan yang mencolok antara nilai indeks organisasi dengan indeks unit pelayanan, hal sebaliknya ditemukan pada rumah sakit dengan tingkat implementasi Manajemen Risiko Klinis yang rendah, nilai indeks organisasi lebih rendah dibandingkan indeks unit pelayanan.

Karakteristik struktur organisasi yang menunjukkan kecenderungan hubungan dengan tingkat kemapanan implementasi Manajemen Risiko Klinis adalah Kelas dan status kepemilikan RS, sedangkan jenis RS tidak menunjukkan kecenderungan hubungan. Faktor lain yang menunjukkan hubungan dalam kemapanan implementasi Manajemen Risiko Klinis di rumah sakit adalah akreditasi, kepemimpinan, pengetahuan staf, dan tersedianya posisi sebagai penanggungjawab atau kordinator program Manajemen Risiko Klinis serta kebijakan rumah sakit.

Pimpinan rumah sakit harus melakukan upaya penguatan komitmen bagi stafnya dan menunjukkan komitmennya secara jelas dan terbuka kepada seluruh staf untuk memotivasi mereka untuk juga ikut mendukung program MRK. Untuk mengefektifkan pelaksanaan program Manajemen Risiko Klinis, Pimpinan harus memasukkan Manajemen Risiko Klinis sebagai salah satu kebijakan strategis rumah sakit dalam upaya peningkatan keselamatan pasien, mengadakan dan mengakomodir 
kegiatan-kegiatan pelatihan manajemen risiko kepada seluruh pegawai dan menentukan penanggungjawab atau kordinator untuk pelaksanaan program ini. Untuk melihat hubungan antara MRK dan kualitas pelayanan kesehatan dengan lebih detail, maka perlu dilakukan penelitian lanjutan tentang hubungan antara tingkat kemapanan MRK dengan keselamatan pasien yang menggunakan instrumen data keluaran klinis yang jelas. Juga dapat dilakukan penelitian tentang hubungan antara masingmasing indeks dengan tingkat kemapanan implementasi MRK untuk mendapatkan data yang lebih akurat dan detail mengenai faktor kunci yang mempengaruhi implementasi MRK di rumah sakit. Penelitian serupa dengan jumlah sampel yang lebih besar perlu dilakukan agar bisa diperoleh data tentang tingkat kemapanan implementasi MRK di Kota Makassar secara lebih detail.

\section{DAFTAR PUSTAKA}

Adibi, H., Khalesi, N., Ravaghi, H., Jafari, M. \& Jeddian, A. R. 2012. Development Of An Effective Risk Management System In A Teaching Hospital. Journal Of Diabetes And Metabolic Disorders, 11, 1-7.

Andaleeb, S. S. 2000. Public And Private Hospitals In Bangladesh: Service Quality And Predictors Of Hospital Choice. Health Policy And Planning, 15, 95-102.

Braithwaite, J., Greenfield, D., Westbrook, J., Pawsey, M., Westbrook, M., Gibberd, R., Naylor, J., Nathan, S., Robinson, M., Runciman, B., Jackson, M., Travaglia, J., Johnston, B., Yen, D., Mcdonald, H., Low, L., Redman, S., Johnson, B., Corbett, A., Hennessy,
D., Clark, J. \& Lancaster, J. 2010. Health Service Accreditation As A Predictor Of Clinical And Organisational Performance: A Blinded, Random, Stratified Study. Quality And Safety In Health Care, 19, 14-21.

Briner, M., Kessler, O., Pfeiffer, Y., Wehner, T. \& Manser, T. 2010. Assessing Hospitals' Clinical Risk Management: Development Of A Monitoring Instrument. Bmc Health Services Research, 10, 1-11.

Briner, M., Manser, T. \& Kessler, O. 2013. Clinical Risk Management In Hospitals: Strategy, Central Coordination And Dialogue As Key Enablers. Journal of Evaluation In Clinical Practice, 19, 363-369.

Carroll, R. 2009. Risk Management Handbook For Health Care Organizations, John Wiley \& Sons.

Dehnavieh, R., Ebrahimipour, H., Jafari Zadeh, M., Dianat, M., Noori Hekmat, S. \& Mehrolhassani, M. H. 2013. Clinical Governance: The Challenges Of Implementation In Iran. International Journal of Hospital Research, 2, 1-10.

Dinkes 2016. Profil Kesehatan Kota Makassar, Dinas Kesehatan Kota Makassar.

El-Jardali, F., Dimassi, H., Jamal, D., Jaafar, M. \& Hemadeh, N. 2011. Predictors And Outcomes Of Patient Safety Culture In Hospitals. Bmc Health Services Research, 11, 1.

Farokhzadian, J., Nayeri, N. D. \& Borhani, F. 2015. Assessment Of Clinical Risk Management System In Hospitals: An Approach For Quality Improvement. 
Global Journal Of Health Science, 7, 294.

Goeschel, C. A., Wachter, R. M. \& Pronovost, P. J. 2010. Responsibility For Quality Improvement And Patient Safety: Hospital Board And Medical Staff Leadership Challenges. Chest Journal, 138, 171-178.

Irfan, S. \& Ijaz, A. 2011. Comparison Of Service Quality Between Private And Public Hospitals: Empirical Evidences From Pakistan. Journal of Quality And Technology Management, 7, 1-22.

Kemenkes 2014. Peraturan Menteri Kesehatan Republik Indonesia Nomor 56 Tahun 2014 Tentang Klasifikasi Dan Perizinan Rumah Sakit. In: Indonesia, K. K. R. (Ed.).

Kemenkes, K. 2011. Standar Akredtasi Rumah Sakit [Online]. Direktorat Jenderal Bina Upaya Kesehatan Kementerian Kesehatan Ri Dengan Komisi Akreditasi Rs (Kars)

Mostafa, M. M. 2005. An Empirical Study Of Patients' Expectations And Satisfactions In Egyptian Hospitals. International Journal Of Health Care Quality Assurance, 18, 516-532.

Needleman, J. \& Hassmiller, S. 2009. The Role Of Nurses In Improving Hospital Quality And Efficiency: Real World Result. Health Affair.

Pretagostini, R., Gabbrielli, F., Fiaschetti, P., Oliveti, A., Cenci, S., Peritore, D. \& Stabile, D. Risk Management Systems For Health Care And Safety Development On Transplantation: A Review And A Proposal. Transplantation Proceedings, 2010. Elsevier, 1014-1016.
Rozita Davoodi, Azadeh Soltanifar, Shaghayegh Rahmani, Golnaz Sabouri, Mahboubeh Asadi, Maryam Zare Hoseini \& Afsaneh Takbiri, F. K. 2014. Clinical Governance: Efficacy Of Establishment In Mashhad Hospital. Journal Of Patient Safety \& Quality Improvement, 2, 4852.

Scully, M. 2005. Clinical Risk Management Guidelines For The Western Australian Health System Information Series No. 8. East Perth, Western Australia: Department Of Health, Government Of Western Australia.

Sheikhtaheri, A., Sadoughi, F., Ahmadi, M. \& Moghaddasi, H. 2013. A Framework Of A Patient Safety Information System For Iranian Hospitals: Lessons Learned From Australia, England And The Us. International Journal of Medical Informatics, 82, 335-344.

Soesanto, R. \& Efendy, H. 2017. Leadership Management Of Military Hospital In Effort To Improve The Patient Safety (Case Study Of Rsal Dr.Mintoarjo). International Journal of Human Resource Studies, 8.

Sugiyono 2015. Metode Penelitian Kombinasi, Bandung, Cv. Alfabeta.

Verbano, C. \& Turra, F. 2010. A Human Factors And Reliability Approach To Clinical Risk Management: Evidence From Italian Cases. Safety Science, 48, 625-639.

Vincent, C. 2011. Patient Safety, John Wiley \& Sons.

Webb, V., Stark, M., Cutts, A., Tait, S., Randle, J. \& Green, G. 2010. One 
Olii, 2019

Model Of Healthcare Provision

Lessons Learnt Through Clinical

Governance. Journal Of Forensic

And Legal Medicine, 17, 368-373.

Who 2014. 10 Facts On Patient Safety. World

Health Organization.

Yousapronpaiboon, K. \& Johnson, W. C.

2013. A Comparison Of Service

Quality Between Private And Public

Hospital In Thailand. International

Journal Of Business And Social

Science, 4.

Zaboli, R., Karamali, M., Salem, M. \& Rafati,

H. 2011. Risk Management

Assessment In Selected Wards Of

Hospitals Of Tehran. Iranian Journal

Of Military Medicine, 12, 197-202.

Zimmer, M., Wassmer, R., Latasch, L., Oberndörfer, D., Wilken, V., Ackermann, H. \& Breitkreutz, R. 2010. Initiation Of Risk Management: Incidence Of Failures In Simulated Emergency Medical Service Scenarios. Resuscitation, 81, 882886. 